研究

\title{
気中放電による電極材移行を用いた表面改質*
}

薩田寿隆** 平井清人**

\section{Surface Modification Using Electrode Transfer Induced by Discharge of Gas}

\author{
Toshitaka SATSUTA and Kiyohito HIRAI
}

\begin{abstract}
A pulsed arc has been applied to deposit an electrode material on a metallic substrate. Die steels are sparked with electrodes of cermets containing both borides $\left(\mathrm{TiB}_{2}, \mathrm{ZrB}_{2}\right)$ and metals $(\mathrm{Co}, \mathrm{Ni})$ in argon atmosphere. A conventional NC EDM machine is used as a pulsed arc generator. A transistor-controlled capacitor circuit is adopted to obtain steep and high current electrical pulses promoting transfer of the electrode materials. Coatings of borides, which are difficult to build up, are deposited onto the substrates. Surfaces of the coatings are irregular and thickness varies in the range of 10 to $50 \mu \mathrm{m}$. No cracks are observed in interfaces between the coatings and the substrates. Vickers hardness value $(0.098 \mathrm{~N}$ load) changes between 1,000 to $3,200 \mathrm{Hv}$ depending on both thickness of the coating and the electrode materials. Wear-out test is performed to investigate wear resistance of the coatings. Although the substrates without a coating are severely worn, the wear impression of the coated substrates is terminated in the coatings. An electrode mass transfer mechanism is observed. The electrode material is not transferred by a single discharge but by a highly concentrated discharge that occurs occasionally at arbitrary locations.
\end{abstract}

key words: EDM, surface modification, electrode transfer, boride

\section{1.はじめに}

近年, 放電加工法を表面改質へ応用する様々な 試みがなされている ${ }^{1) 4)}$ 。なかでも，放電加工油 中で電極材を放電により溶融・飛散させ改質層を 形成する手法においては，硬質な皮膜が形成され ている．実用面でも，プレス金型，冷間鍜造金型 および切削工具一適用し，優れた耐摩耗性を有す ることが確認されている ${ }^{5)}$. しかしながら，放電 加工油中で改質を行っているため, 加工油が放電

* 電気加工学会全国大会 (1999) にて発表

** 神奈川県産業技術総合研究所 (海老名市下 今泉 705-1)

E-mail : satsuta@kanagawa-iri.go.jp
により分解して生じた炭化雾囲気中で改質を行う ことになり，この手法では形成できる改質層は炭 化物に限定されている.

一方, 放電加工油を用いずアルゴンなどの不活 性な気中で放電を発生させ電極材を移行し改質層 を形成するならば，用いる電極材に応じて，炭化 物のみならず金属, 窒化物, およびホウ化物など 様々な組成の改質層を形成可能と思われる.

気中放電を用いた表面改質法としては，古くか ら放電被覆法が知られており，超硬合金成分をは じめとする様々な組成からなる改質層が形成され ている ${ }^{6)}$. 奥宮らは酸室化物を含む改質層が形成 可能なことを報告している ".さらに，表面改質 ではないが, 早川らにより電極の移行・付着現象 
を利用した形状創成が試みられている ${ }^{8)}$ 。このよ うに気中放電は広い自由度を有している。

本研究では，気中放電による形成が報告されて いないホウ化物からなる硬質層を形成することを 試みた，電極材として，高融点，高硬度，および 高耐酸化性といった特徵を有し表面改質材として 優れた特性が期待できる $\mathrm{TiB}_{2}$ (二ホウ化チタン) や $\mathrm{ZrB}_{2}$ (二ホウ化ジルコニウム) からなるサー メットを用いた．アルゴンガス中で放電を発生さ せ，ダイス鋼に対して表面改質を試みた。そして 改質層特性と改質層形成メカニズムについて検討 した.

\section{2. 実験方法}

実験装置の構成をFig. 1に示す，放電雾囲気を 制御できるように電極及び工作物の周囲をポリプ ロピレン製の容器で覆った，供給ガスは，この容 器の側面より導入し, 電極と容器の間隙を通って 容器上面より流出する. 電流センサーおよびデジ タル・オシロスコープを用い，放電時の電流，電 圧を測定した。また，GPIB を介してオシロスコ 一プとパソコンを接続し，オシロスコープのデー タをパソコンに取り込み処理し，放電現象の解析 に用いた。

実験条件をTable1に，電極材の組成比をTable2 にそれぞれ示す．工作物は，いずれも熱処理（焼

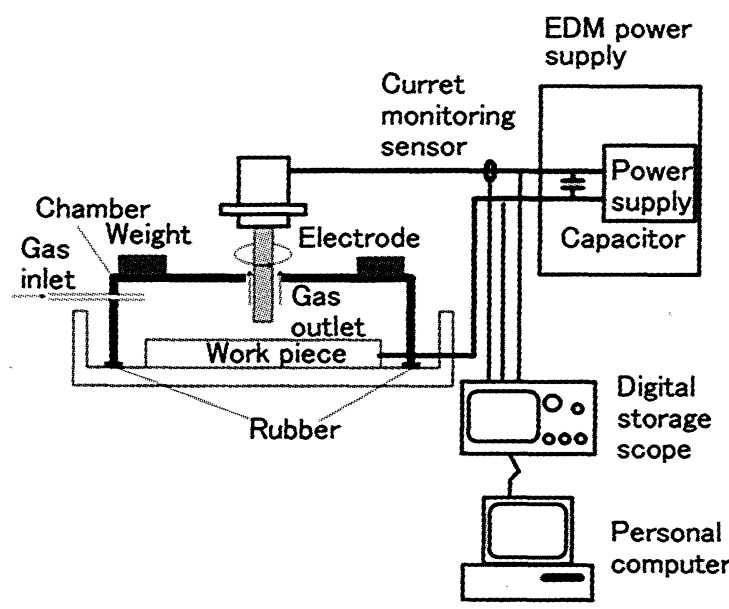

Fig. 1 Experimental setup
Table1 Experimental conditions

\begin{tabular}{l|l}
\hline EDM machine & Sodick A30R NF-40 \\
Work piece & DC53, SKD61 \\
Electrode & TiB, $\mathrm{ZrB}_{2}$ cermet $(\phi \quad 7 \mathrm{~mm})$ \\
Atmospheric gas & argon $5 \mathrm{l} / \mathrm{min})$ \\
Polarity & electrode : + \\
Open voltage & $280 \mathrm{~V}$ \\
Discharge duration & $10 \sim 20 \mu \mathrm{s}$ (measured) \\
Discharge interval & $16 \mu \mathrm{s}$ (set) \\
Discharge current & $50 \sim 140 \mathrm{~A}$ (measured) \\
Servo voltage & $135 \mathrm{~V}$ \\
Electrode rotating rate & $200 \mathrm{~m}^{-1}$ \\
Coating duration & $10,20,30,60 \mathrm{~min}$ \\
\hline
\end{tabular}

Table2 Electrode compositions (mass \%)

\begin{tabular}{l|l}
\hline $\mathrm{TiB}_{2}: \mathrm{Co}$ & $85: 15,80: 20,75: 25$ \\
$\mathrm{TiB}_{2}: \mathrm{Ni}$ & $85: 15$ \\
$\mathrm{ZrB}_{2}: \mathrm{Co}$ & $85: 15$ \\
$\mathrm{ZrB}_{2}: \mathrm{Ni}$ & $85: 15$ \\
\hline
\end{tabular}

入れ・焼戻し）を施した，冷間ダイス鋼 DC53（大 同特殊鋼製 SKD11 改良鋼) および熱間ダイス鋼 SKD61 を用いた. 電極は, Table2 に示す組成か らなるサーメットを用いた，放電雾囲気は改質層 と電極の酸化を防止することを目的にアルゴンと した．実験においては放電発生に先立ち，アルゴ ンガスで容器内を 1 分間置換している. 予備実験 において，電極極性がマイナスの場合には電極材 の移行が起こらなかったので, 電極極性をプラス とした。 また，トランジスターパルスよりコンデ ンサーパルスのほうが放電が安定に発生しかつ電 極材が工作物へ移行・堆積しやすい傾向にあっ た．そこで，放電加工機に備え付けられているト ランジスター制御コンデンサー回路を用いた．電 極の片あたりを防ぐため電極を回転させた.

改質時間を $10 \sim 60$ 分と変化させて実験を行 い, 実験終了後, 改質層の構成相, 改質層形態, 改質層の硬さ，および耐摩耗性について調べた. また, 改質層形成のメカニズムについて検討した。 


\section{3. 実験結果と考察}

\section{1改質層の構成相}

本手法で用いる放電は，電流・電圧值から判断 すると，アークプラズマである．同様なアークプ ラズマを用いて皮膜を形成するプラズマ溶射にお いては, プラズマの熱により $\mathrm{TiB}_{2}$ が分解, さら に場合によっては反応し, $\mathrm{TiB}_{2}$ は単相では形成 困難なことが報告されている"。 そここで改質層に $\mathrm{TiB}_{2}$ が形成されているか否かを確認するために, 改質層の構成相を X 線回折により調べた.

Fig. 2に改質層の X 線回折パターンの一例を示 す.いずれの電極材とダイス鋼の組み合わせにお いても改質層には $\mathrm{TiB}_{2}$ が形成されていることが 確認できる. また同定した $\alpha \mathrm{Fe}$ は母材のものと 思われる，他の電極と工作物の組み合わせでも同 様に, 電極材のホウ化物と母材の $\alpha \mathrm{Fe}$ のピーク が同定された。

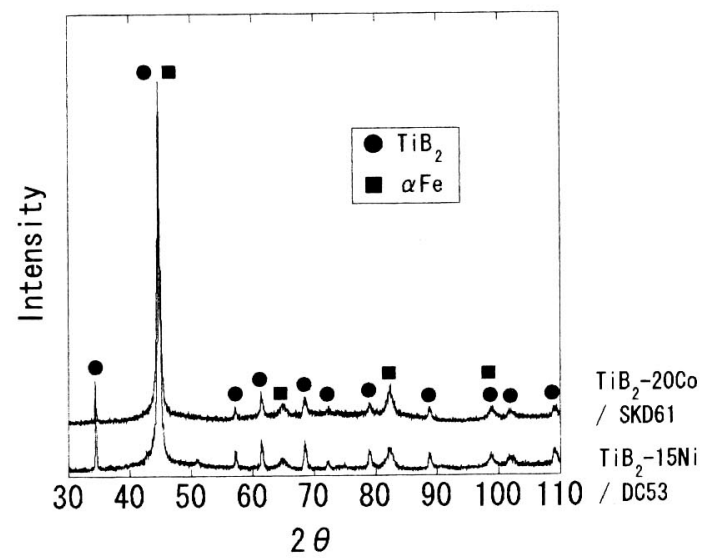

Fig. 2 X-ray diffraction patterns of the coatings (coating duration : $30 \mathrm{~min}$ )

\section{2改質層形態}

工作物は気中放電により加工されることなく， 工作物上に改質層が形成された。 Fig. 3に改質層 外観の SEM（走査電子顕微鏡）写真を示す。い ずれの改質時間においても改質層形状は凹凸であ り，明瞭な放電痕は見られない，改質時間が長く なるにつれ凸部は増える。

改質層の断面を研磨・エッチング（腐食液 : ナ イタル）し光学顕微鏡で観察した。 Fig. 4に断面
組織の一例を示寸，母材の上には白層と改質層が 見られる，白層の組成は母材と変わらないことか ら，放電の熱により組織が変化した熱影響層であ ると思われる．改質層の厚さは場所により異なり およそ $10 \sim 50 \mu \mathrm{m}$ である. また局部的に改質 層が未形成な領域が見られる．EPMA（電子線マ

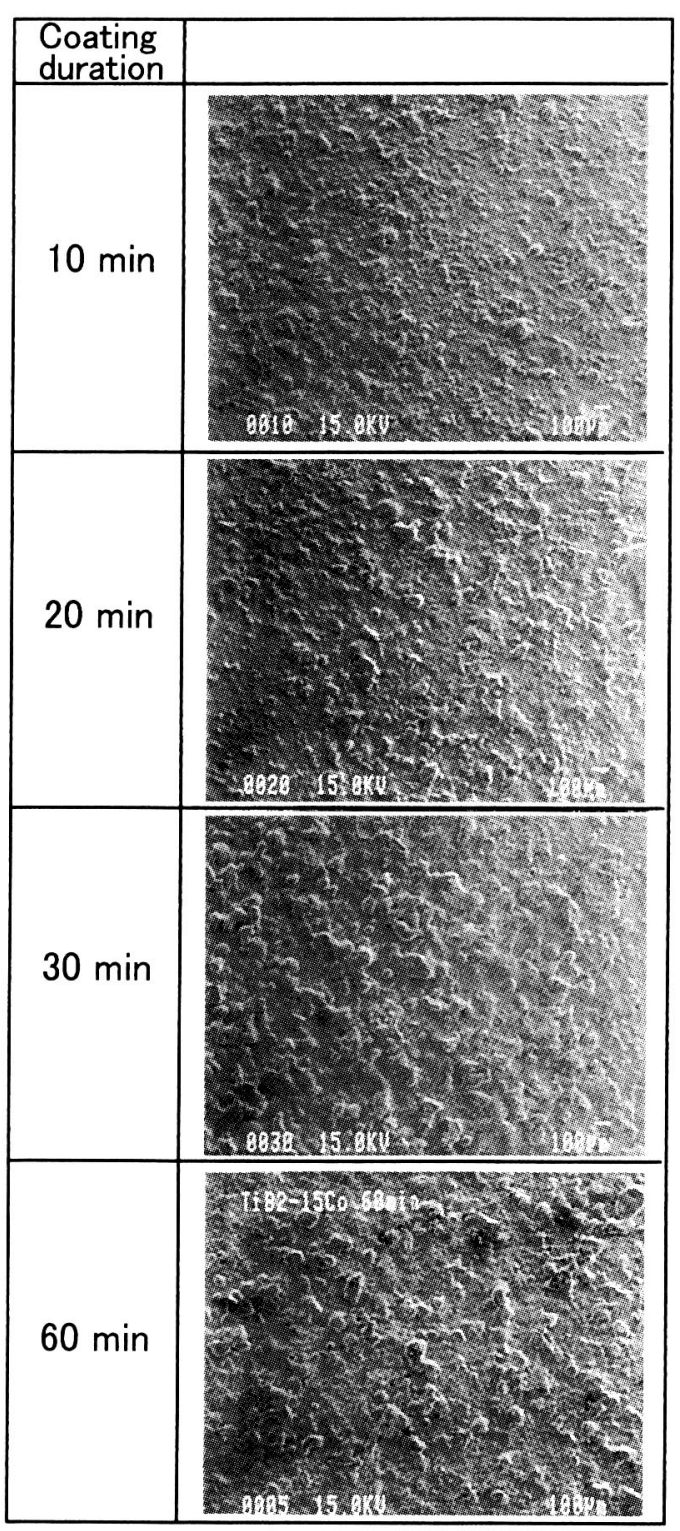

Fig. 3 Secondary Electron Images of the coatings (electrode : $\mathrm{TiB}_{2}-15 \mathrm{Co}$, work piece : $\mathrm{DC} 53$ ) 


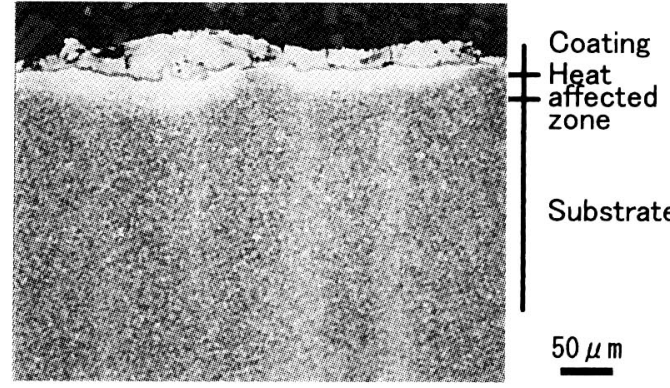

Fig. 4 Microsection of a coating (electrode : $\mathrm{TiB}_{2}-15 \mathrm{Co}$, work piece : SKD61, coating duration : $30 \mathrm{~min}$ )

イクロアナライザ）により分析すると，厚い改質 層と母材との界面および薄い改質層中では, 電極 と母材の成分が混合していることが分かる，一方 厚い改質層中では電極成分のみが認められた，改 質層中には空孔および垂直方向にクラックが，ま た改質層と熱影響層との境界には空孔が，それぞ れ認められる．改質層中にはクラックおよび空孔 が見られるものの，母材(厳密には熱影響層)との 界面にはクラックは見られず，改質層と母材の密 着性は良いと思われる．他の電極材と工作物の組 み合わせにおいても同様な断面形態が見られた.

\section{3 改質層の硬さ}

改質層の硬さをマイクロビッカース硬さ試験機 を用いて調べた。測定荷重は $0.098 \mathrm{~N}$ とし断面よ り各測定個所につき 5 箇所ずつ測定した。その結 果をFig. 5にまとめて示す.

電極材が TiB2-15Co を例に示すように，同一電 極材において左側が薄い改質層の硬さを，右側が 厚い改質層の硬さをそれぞれ示している．電極材 と工作物のいずれの組み合わせにおいても，改質 層が薄いところでは, 厚いところに比心゙硬さは低 下している。これは，先に述べたように，薄い改 質層では，電極材と母材の成分が混合し，硬さに 寄与するホウ化物が希釈されたためと考えられ る.また, 電極が $\mathrm{TiB}_{2}-15 \mathrm{Co}, \mathrm{TiB}_{2}-15 \mathrm{Ni}, \mathrm{ZrB}_{2}-15 \mathrm{Co}$, および $\mathrm{ZrB}_{2}-15 \mathrm{Ni}$ において, 改質層の厚い場所で の最大硬さは, 各々のホウ化物単体の硬さ $\mathrm{TiB}_{2}$ $\left(3,400 \mathrm{HV}^{(0)}\right)$ および $\mathrm{ZrB}_{2}\left(2,200 \mathrm{HV}^{(0)}\right)$ とほぼ同等な 値となっている.

$\mathrm{TiB}_{2}-\mathrm{Co}$ 系電極を用いた場合，金属成分の割合

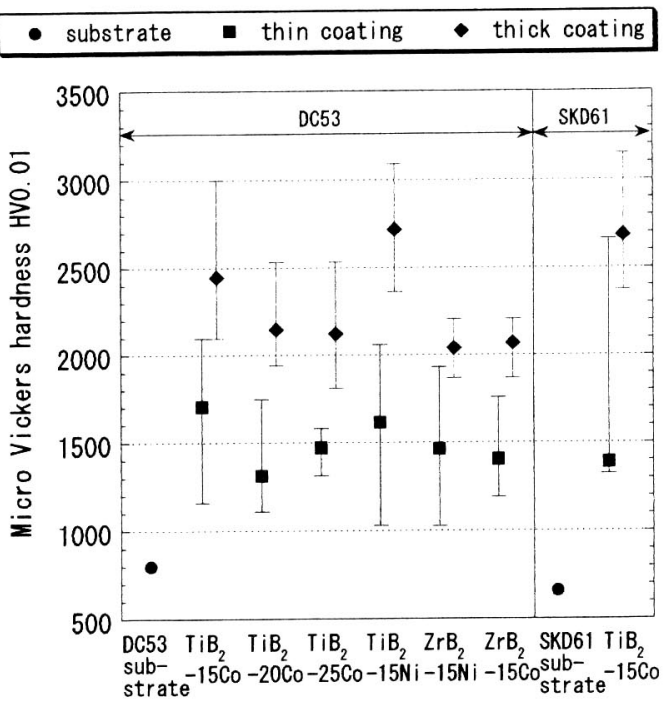

Fig. 5 Influences of the electrodes and the work pieces on hardness of coatings (coating duration $30 \mathrm{~min}$ )

が多くなるにしたがい厚い改質層の硬さは低下し ている.

$\mathrm{TiB}_{2}-15 \mathrm{Co}$ と $\mathrm{TiB}_{2}-15 \mathrm{Ni}, \mathrm{ZrB}_{2}-15 \mathrm{Co}$ と $\mathrm{ZrB}_{2}-15 \mathrm{Ni}$ を比較すると用いるバインダの金属成分の違いに よる硬さの大きな差は見られない.

$\mathrm{TiB}_{2}-15 \mathrm{Co}$ において, 薄い改質層では SKD61 のほうが DC53より平均的な硬さは低下している が，厚い改質層では工作物の違いによる硬さの大 きな差は見られない。

このように，改質層が厚いほど硬さの值は大き くなり，さらにバインダの金属成分が少ない場合 には，ホウ化物単体の硬さに近づく，すなわち改 質層の硬さはホウ化物の種類および改質層中にお けるその割合により決まると考えられる。

\section{4 耐摩耗性}

改質層の耐摩耗性を大越式摩耗試験機を用いて 評価した。“3.2 改質層形態”で述べたように，改 質層と母材の密着性はよいものと思われる。しか し，電極材が局所的に堆積した場合などは，改質 層は一般的に脆いサーメットから形成されている ため，母材との界面を残し離脱しやすいと予想さ れる，離脱した改質層は，摩耗試験において遊離 砥粒と同様の挙動を演じ, 摩耗試験に悪影響を与 えると思われる，そこで，試験前に超硬合金製の 
試試験片で改質層をこすり，離脱しやすい部分を あらかじめ除去した．Table3に試験条件を，

Table3 Wearing-out test conditions

\begin{tabular}{l|l}
\hline Ring material & SUJ2 $(60 \mathrm{HRC})$ \\
Sliding speed & $1.63 \mathrm{~m} / \mathrm{s}$ \\
Sliding distance & $600 \mathrm{~m}$ \\
Final load & $60.8 \mathrm{~N}$ \\
Lubricating oil & None \\
\hline
\end{tabular}

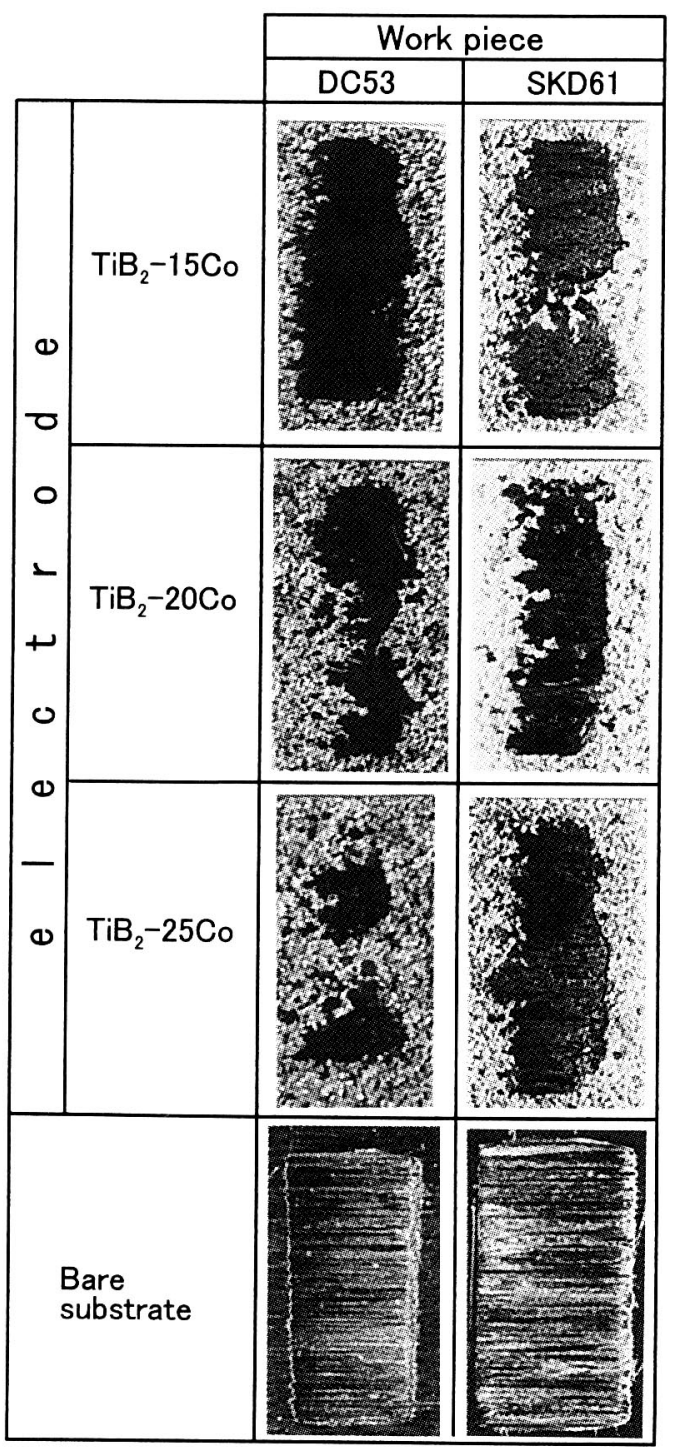

$1 \mathrm{~mm}$

Fig. 6 Appearance of worn coatings (coating duration: $30 \mathrm{~min}$ )
Fig. 6に摩耗試験後の改質層の外観の一例をそれ ぞれ示す．改質層上に黒く見える領域および母材 面上に横方向に擦過痕が生じている領域が摩耗痕 の全体像である. 改質層上の摩耗痕は母材面上の ものと同程度の大きさのものや，局所的に摩耗し ているものなど，様々な形状を呈している。いず れの場合も, Fig.7の摩耗痕の拡大 SEM 写真に 見られるように, 改質層の凸部が損耗するのみで， 摩耗は改質層で止まっている。外観で摩耗痕の形 状に差が生じるのは次のように考えられる. 改質 層の凸部に高いところがあると，そこでリングが 当たり始める．凸部は改質層が厚いところである ので硬さの值は大きく, 摩耗の進行が妨げられそ の結果摩耗痕が小さくなる。一方, 改質層の凸部 の高さが揃っている場合には，リングが改質層に 均一に当たり摩耗痕の外観が大きくなると思われ る.

Fig.6 で示した以外の電極材と工作物の組み合 わせにおいても摩耗痕は改質層を突き抜けること なく，改質を施すことにより母材は保護されてい ることが分かった。

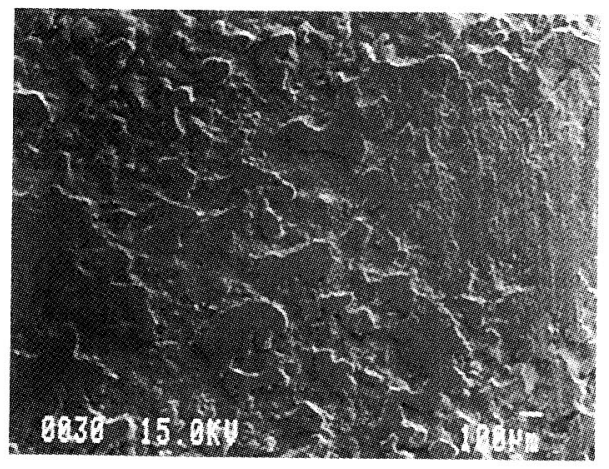

Fig. 7 Secondary Electron Image of a worn coating (electrode: $\mathrm{TiB}_{2}-15 \mathrm{Co}$, work piece: DC53, coating duration: $30 \mathrm{~min}$ )

\section{5 改質層形成のメカニズム}

改質層の形成には放電現象が大きく影響すると 考えられる.放電形態はFig. 8の放電波形に見ら れるように2つの形態が観察された。すなわち, Fig.8 中のC，Dのように放電遅れ時間を伴って単 発放電が生じる場合, およびA，Bのように放電遅 
れ時間を伴った 1 発目の放電が発生した後, 連続 して放電が生じる場合である. 後者の場合, 2 発 目以降の放電は電圧の立ち上がりとともに生じて いる，電压が再度印加された時には，直前の放電 によるプラズマが極閒に残存しており，極間の絶 縁耐力が低下したためこのような現象が生じたと 考えられる。この場合，放電が同じ場所で集中し ているものと予想される. このように, 単発放電 と集中放電の 2 つの放電形態が観察される。これ らの放電が改質層形成に及ぼす影響を次に考察す る.

Fig. 9に工作物上に生じた単発放電痕の SEM 像とその一部を应大した EPMA の分析結果を示 す、 Ti - K $\alpha$ 線のプロファイルは右に行くにした がい低下しているが，これは試料面の傾斜の影響 と考えられる：このことを考虑すると母材と放電 痕ではチタンの量に差が見られない。すなわち， 単発放電では，電極材は工作物へ移行・堆積しな いと思われる.

Fig. 10に見られる改質層断面の光学顕微鏡写真 においては，改質層が厚いところで，熱影響層の 領域が大きいことが確認できる。ここでは単位時 間あたりの入熱量が大きいと予想される。すなわ ち放電の集中が生じたものと思われる.

以上の結果から，改質層の形成は放電の局所的

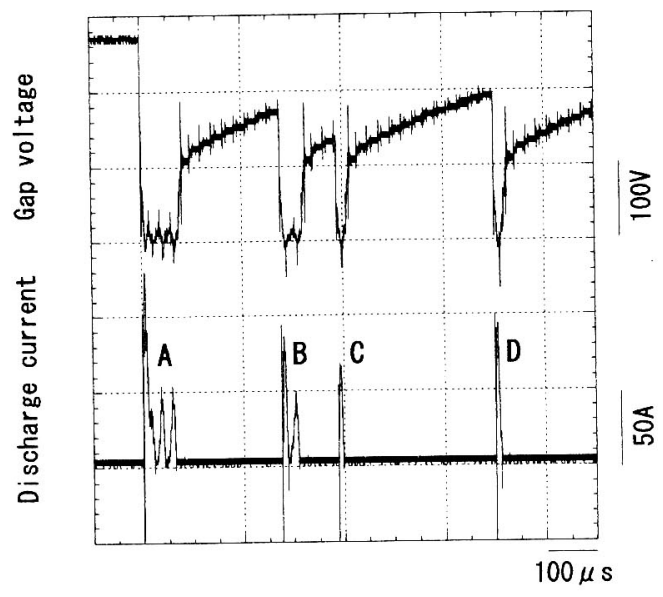

Fig. 8 Gap voltage and discharge current (electrode :TiB2-15Co, work piece :DC53)
集中によりなされるものと思われる.

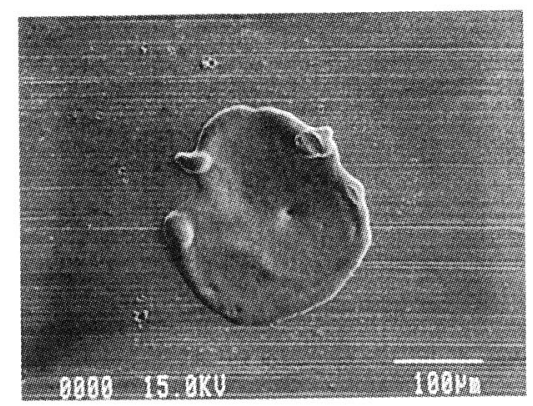

(a) whole appearance

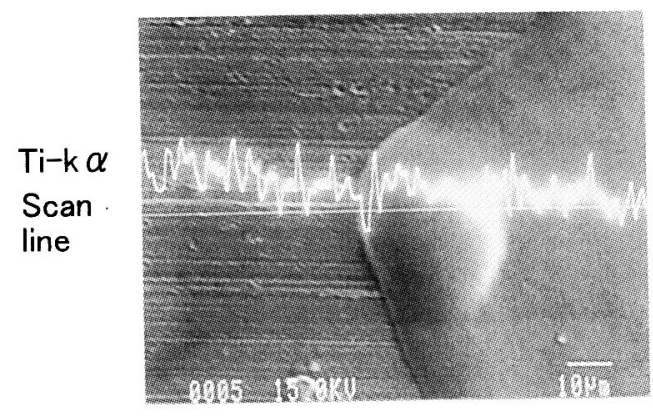

(b) Ti line profile

Fig. 9 Secondary Electron Image of a crater generated by a single pulse and $\mathrm{Ti}$ line profile (electrode $\mathrm{TiB}_{2}-15 \mathrm{Co}$, work piece : DC53)

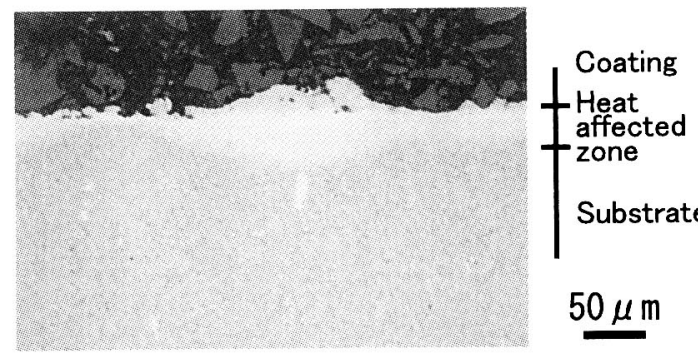

Fig. 10 Microsection of a coating (electrode:

$\mathrm{TiB}_{2}-15 \mathrm{Co}$, work piece: DC53, coating duration: 10 $\min$ )

\section{6 改質層体皘}

Fig. 11に改質層体積の経時変化を示す. 改質に よる重量変化を測定し, それを各電極材の組成比 
に応じた密度をもとに体積に換算した，各条件に つき 3 試料の重量変化を測定した。いずれの電極 材においても改質時間に対する体積の勾配すなわ ち改質層の堆積速度は改質時間 20 分を境に低下 する. また, $\mathrm{TiB}_{2}-15 \mathrm{Co}$ と他の 2 つの電極材を比 較すると，電極材の金属成分の割合が多いほうが 改質層体積が大きい傾向にある.

これらの現象が生じた原因をまず放電頻度の観 点から調べた。“3.5 改質層形成のメカニズム”で 述べたように，改質層の形成は集中放電によりな されるものと思われる，放電が集中した場合，2 発目以降の放電は，コンデンサーの充電時間が短 いため, 放電電流のピークが低くなる，その值は 最大で $55 \mathrm{~A}$ 程度であった。 そこで $60 \mathrm{~A}$ 以下の放 電数を測定すれば，改質層形成に寄与する集中放 電の数が計測できると考え, これを測定した. 測 定は, 電流センサーからの電流值をデジタルオシ ロスコープにてデジタル化し，GPIB を介してパ ソコンにそのデータを転送し, 放電数を測定した. およそ 2 秒のサンプリング周期で各々の放電時間 $250 \mathrm{~ms}$ の間に発生した放電数を計測した. Fig. 12 には放電数および回帰曲線を示している。

$\mathrm{TiB}_{2}-25 \mathrm{Co}$ は $\mathrm{TiB}_{2}-20 \mathrm{Co}$ と同様な傾向を示すため 省略した. どちらの電極においても 60 分の改質 時間にわたって放電数は増加傾向にあるが,

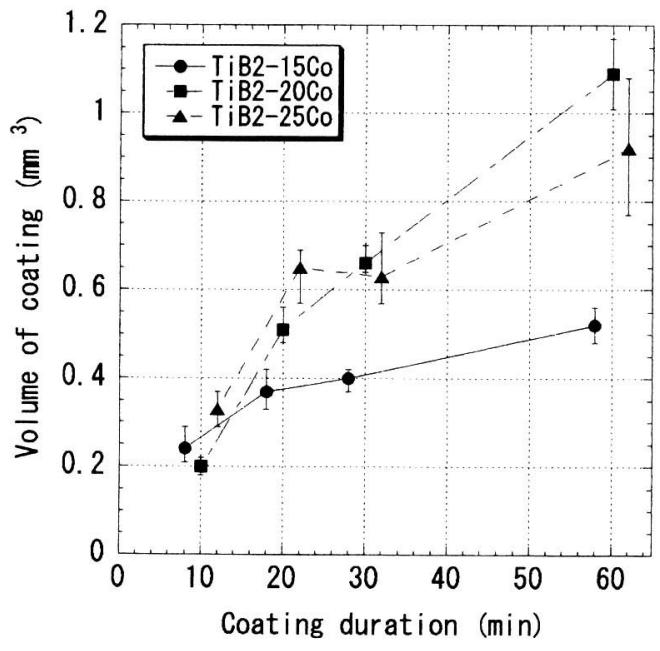

Fig. 11 Volume increase of coating (work piece: DC53)
Fig.11に見られたような改質時間 20 分を境に堆 積速度が変化する理由は見あたらない。また, 放 電数はわずかに $\mathrm{TiB}_{2}-20 \mathrm{Co}$ 電極のほうが少ない が, Fig.11 に見られるような電極の違いにより改 質層体積に 2 倍近くの差を生じるような現象は認 められない.したがって改質層の堆積速度の経時 変化や電極材の違いによる改質層体積の差は, 放 電頻度の違いが原因ではなく，他の理由によるも のと考えられる.

本手法と同様に気中で放電を発生させ, 電極材 を移行し改質層を形成する放電被覆においては， 電極材と改質層の堆積量に関して次のことが報告 されている ${ }^{11)}$. 超硬合金（コバルトをバインダー とした WC (炭化タングステン) の焼結材）を電
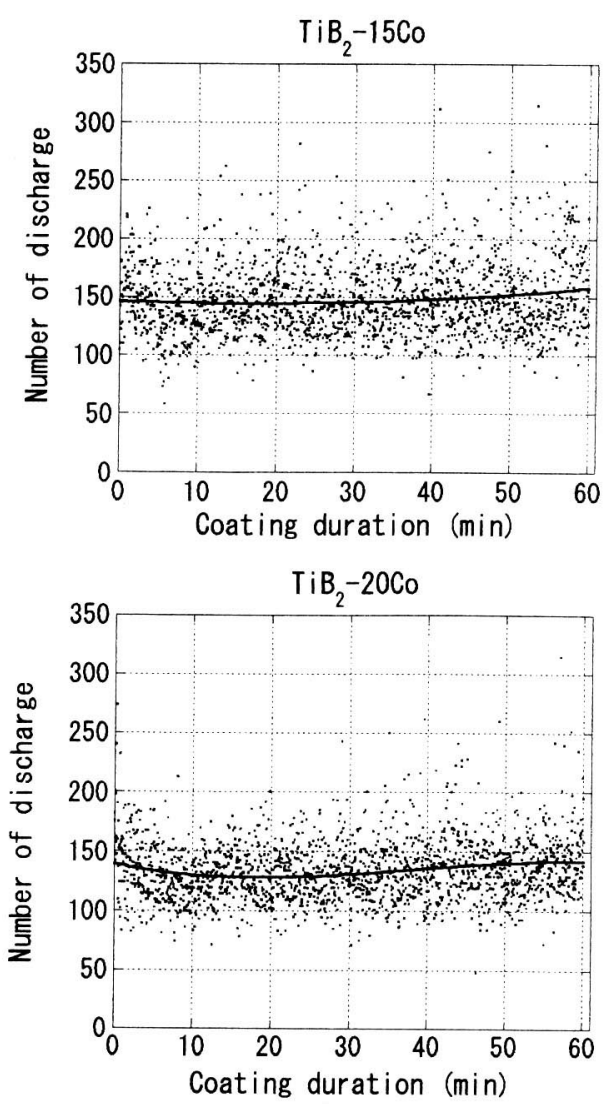

Fig. 12 Number of discharge occurred per $250 \mathrm{~ms}$ (work piece : DC53) 
極とした場合には，改質時間が長くなると改質層 は破壊され, 改質首体積は最大值をとった後減少 する.一方, 金属電極ではこのようなことは起こ らず，時間とともに体積は増加する．これらのこ とから推察すると，本手法でも超硬合金と同じく 金属をバインダーとした化合物（ホウ化物）の焼 結体を電極としているため，放電被覆と同様な現 象が生じたものと考えられる.すなわち，改質時 間が長くなると改質層の一部が破壊され堆積速度 が低下するものと思われる．また，電極材の金属 成分が多いほど改質層は破壊されにくく， $\mathrm{TiB}_{2}-20 \mathrm{Co}$ および $\mathrm{TiB}_{2}-25 \mathrm{Co}$ 電極のほうが $\mathrm{TiB}_{2}-15 \mathrm{Co}$ 電極より改質層体積が大きくなったと 考えられる.

\section{4. まとめ}

気中放電を用いてホウ化物からなる改質層の形 成を試みた。 その結果以下の知見が得られた.

1) 電極材のホウ化物は他の相に変化すること無く 形成される。

2)改質層の厚さは場所により $10 \sim 50 \mu \mathrm{m}$ と異 なる.

3) 改質層中のホウ化物の種類および割合により改 質層の硬さは決まると考えられる．電極のバイ ンダの金属成分が少ない場合には, ホウ化物単 体の硬さに近づく.

4)電極材と工作物のいずれの組み合わせにおいて も摩耗痕は改質層中で止まっており，改質を施 すことにより母材は保護される.

5) 改質層の形成は放電の集中によりなされると推 察される。

6)改質時間が長くなるにつれて, 改質層の堆積速 度は低下する．また電極材の金属成分が多いも
ののほうが改質層体積は大きい.

\section{参考文献}

1) 毛利尚武, 齋藤長男: 表面改質放電加工, 精密 工学会誌, 64,12(1998) 1715 .

2) 岡田晃, 宇野義幸, 平尾和久, 高木俊: チタン 電極を用いた炭素粉末混入放電加工による表面 改質, 電気加工学会誌, 33,73(1999) 31 .

3) 塚原秀和, 南久, 増井清徳, 出水敬, 兽根匠: 放電加工によるチタンの表面改質, 電気加工学 会誌, 33,74(1999) 9.

4) 佐野正明, 日原政彦, 八代浩二：高品質放電加 工面の創成に関する研究 (第二報), 電気加工学 会全国大会 (2000) 講演論文集, (2000) 87.

5) 後藤昭弘, 毛吕俊夫, 松川公映 : 放電表面処理 装置 (EDCOAT) の開発, 電気加工学会誌, 34,75 (2000) 38 .

6) Roger N. Johnson, G. L. Sheldon : Advances in the electrospark deposition coating process, J.Vac.Sci.Technol.A4 (6),Nov/Dec (1986) 2740.

7) 奥宮正洋, 恒川好樹, 近藤浩, 吉田憲司: パル ス放電によるアルミニウム上への酸窒化アルミ ニウムの生成，日本金属学会誌，61,2(1997) 153.

8) 早川伸哉, ORI Ricardo Itiro, 糸魚川文広, 中村 隆, 松原十三生: 微細放電付着加工による 3 次 元形状創成法, 精密工学会誌, 66,12(2000) 1943.

9)加藤周一郎, 金気昭一, 浦山清, 伊ヶ崎文和 : Ti-B 複合粉末のプラズマ溶射によって合成された皮 膜の特性, 溶射, 29,1(1992) 30 .

10）日本金属学会編：金属データーブック, 丸善 (1984) 136.

11)電気加エハンドブック編集委員会編 : 電気加工 ハンドブック，日刊工業新聞社(1970) 111.

(2001 年 2 月 20 日受付) 